\title{
Contrastes e contrastes encobertos na produção da fala de crianças**
}

\section{Contrast and covert contrast in the speech production of children}

\section{Larissa Cristina Berti*}

*Fonoaudióloga. Doutora em Linguística pelo Instituto de Estudos da Linguagem (IEL) da Universidade Estadual de Campinas - Unicamp. Docente e Pesquisadora Vinculada ao Departamento de Fonoaudiologia da Universidade Estadual Paulista (Unesp), no Âmbito do Programa de Jovens Pesquisadores em Centros Emergentes de Pesquisa da Fundação de Amparo à Pesquisa do Estado de São Paulo (Fapesp). Endereço para correspondência: R. Antônio Lorencil Serafim, 116 - Marília - SP

CEP 17514-600

(larissa.berti@uol.com.br).

**Trabalho Realizado no Departamento de Fonoaudiologia da Universidade Estadual Paulista - Campus de Marília.

Artigo Original de Pesquisa

Artigo Submetido a Avaliação por Pares

Conflito de Interesse: não

Recebido em 20.11.2009.

Revisado em 20.04.2010; 01.11.2010.

Aceito para Publicação em 18.11.2010.

\begin{abstract}
Background: speech acoustics. Aim: to acoustically analyze the substitution between $/ \mathrm{t} / \mathrm{and} / \mathrm{k} /$ in the speech production of children with typical and deviant acquisition process in order to identify and quantify the presence of covert contrast. Method: the experiment involved the repetition of words that combined $/ \mathrm{t} /$ and $/ \mathrm{k} /$ with $/ \mathrm{a} /$ and $/ \mathrm{u} /$ in stressed position. Participants were 9 children divided in three groups: children in the acquisition process of the phonological contrast (G1); children with phonological disorder (G2); and children with typical productions (G3). The speech productions were analyzed and edited using software Praat. The acoustic parameters adopted were: burst spectral characteristics; CV transition and durational characteristics. Duration parameters were analyzed by Friedman ANOVA while the other parameters were analyzed using two-way ANOVA and Hierarchical Linear Modeling. The adopted statistical significance level was of 0.05 . Results: acoustic analysis indicated the presence of covert contrast in the productions of children in G1 and G2 (80\% and 57.14\% of substitutions respectively). In addition, acoustic analysis revealed differences in how well the children differentiated the two occlusives and which acoustic parameters were used to differentiate them. Conclusion: a lot of the substitutions presented in the speech of children in typical and deviant acquisition process are in fact covert contrasts. Moreover, the acoustic analyses allowed the detection of differences in the fine phonetic detail of children's speech production.
\end{abstract}

Key Words: Child; Speech Acoustics; Phonetics.

\section{Resumo}

Tema: análise acústica da fala. Objetivo: analisar acusticamente as "substituições” envolvendo o contraste entre /t/ e /k/ na fala de crianças em aquisição típica e desviante do contraste acima referido, a fim de identificar e quantificar a existência de contrastes encobertos. Método: foi elaborado um experimento de produção de fala que envolveu a repetição de palavras, que combinavam /t/ e / $/ \mathrm{com} / \mathrm{a} / \mathrm{e} / \mathrm{u} / \mathrm{na}$ posição acentuada, por 9 crianças divididas em três grupos: crianças em processo de aquisição do contraste investigado (G1); crianças com transtorno fonológico (G2) e crianças com produções típicas (G3). Com o uso do software Praat, as produções foram editadas e analisadas de acordo com os seguintes parâmetros acústicos: características espectrais do burst; transição CV e características temporais. Os testes estatísticos utilizados foram ANOVA de Friedman e Manova. A significância estatística adotada foi menor que 0,05. Resultados: tanto nas produções das crianças do G2 quanto nas produções das crianças do G1, detectamos, em grande medida ( $80 \%$ e 57,4\%, respectivamente), a presença de contrastes encobertos nos erros de substituição das oclusivas investigadas. Adicionalmente, a análise acústica revelou diferenças em como as crianças utilizam as pistas fonético-acústicas para marcarem a distinção entre /t/ e /k/. Conclusão: muitas das substituições presentes da produção de fala de crianças em processo de aquisição típico e desviante tratam-se na verdade de contrastes fônicos encobertos. Além disso, o uso da análise acústica permitiu a detecção de diferenças sutis da produção da fala das crianças.

Palavras-Chave: Acústica da Fala; Criança; Fonética.

Referenciar este material como: 


\section{Introduction}

Studies of different languages of the world concerning children speech with and without production problems1,2,3,4,5,6 have evidenced, by using an instrumental methodology (acoustic and/or articulatory), an intermediate phase in the process of acquisition of a particular phonic contrast suggested by the presence of the so-called "covert contrast", present not only in the beginning of language acquisition, but also in the so-called deviation of phonetic-phonological development.

The expression "phonic covert contrast" 7 (covert contrast) is used to describe what is categorized as audibly imperceptible, however acoustically and articulatorily detectable phonic contrasts.

The hypothesis of this study is that many of the phonic substitutions audibly detected in children speech going through typical and deviant language acquisition are, in fact, covert contrasts.

Thus, the aim of this current study was to acoustically analyze the "substitutions" involving phonic contrast between /t/ and / $\mathrm{k} /$, in the speech of children going through typical and deviant language acquisition of the contrast previously mentioned, in order to identify and quantify the presence of covert contrasts.

\section{Method}

Subjects: This study was approved by the Committee of Ethics in Research from the Faculty of Sciences - FFC/ UNESP - Marília, under protocol number 3499/2006. Three groups of children were selected to take part in this study: (i) 03 children in acquisition of the contrast between $/ \mathrm{t} /$ and $/ \mathrm{k} /$, average aged 35,33 months (GI); (ii) 03 children with phonological disorder who presented substitutions between $/ \mathrm{t} /$ and $/ \mathrm{k} /$ in speech production, average aged 59 months (GII) and; (iii) 03 children with typical production of the contrast mentioned, average aged 64 months (GIII).

\section{Production Experiment}

Material: the stimulus used in the production experiment consisted of disyllabic words stressed in the stressed in the first syllable matching the stops /t/ and $/ \mathrm{k} /$ with the vowels $/ \mathrm{a} /$ and $/ \mathrm{u} /$ in stressed position: /'taku/ (baseball bat) X/'kaku/ (shard) and/'kuba/ (sink) $\mathrm{X} /$ 'tuba/ (tuba). The context vowel /i/ was excluded because $/ t /$ coming before is produced as the affricate /t?/.
Each child was recorded inside an acoustic booth set at a Kindergarten School with MARANTZ digital recorder, model PMD 670 attached to SHURE cardioid dynamic microphone, model 8800. PRAAT software 5.0.38 was used to analyze the data, while STATICA software version 6.0 was used for statical analysis.

Procedure: the experimental procedure was held by asking the kids to repeat each word five times inside the carrier sentence: "Say target word very beautifully", involving the kids in a ludic activity, adding up to 180 tokens, therefore, favoring the acoustic analysis of the data and further statical treatment of such data:

$$
\begin{aligned}
& \text { 05(repetitions) X } 2 \text { (vowels) X } 2 \text { (stops) X } 9 \text { (subjects) } \\
& =180 \text { tokens }
\end{aligned}
$$

\section{Criteria of data analysis}

Audio-perceptive analysis: a phoneticist living in the same region of the subjects of the study wrote out all the 180 occurrences related to the children's productions gotten on the recordings. The phoneticist wrote out the children's productions as correct or incorrect taking into account the target production of the occlusives $/ \mathrm{t} /$ and $/ \mathrm{k} /$. The productions written out as incorrect were characterized by omission errors, substitutions or distortions of the stops. One month after the first writings, the phoneticist wrote out all the data again. Through an intra-subject agreement analysis, we obtained an agreement percentage of 95\% (57/60).

Acoustical Analysis: The phonetic-acoustical parameters adopted in the analysis were: (1) parameters related to the spectral characteristics of the burst: spectral peak and spectral moments (centroid - M1, standard deviation - M2, skewness - M3, kurtosis M4); (2) formant transition of the adjacent vowels to the stops and; (3) parameters related to the time pattern: duration (absolute and relative) of the closure, burst and formant transition.

Statistical Analysis: a two-way ANOVA was used for each of the subjects' productions separately, and Scheffé Pós-hoc. The intra-subject factors were stops ( $/ \mathrm{t} /$ and $/ \mathrm{k} /$ ) and the vowels $(/ \mathrm{a} /$ and $/ \mathrm{u} /$ ), and the dependent variables were the eight acoustical parameters mentioned above. After the two-way ANOVA, we used the Linear Hierarchical Model9 to determine which acoustical parameters are necessary to distinguish the stops investigated. In this analysis we were able to separate typical contrasts from covert contrasts.

The statistical tests used were applied to the productions followed by /a/ and /u/ separately. Statistical significance was set at $0,05(p<0,05)$. In 
addition, the results in which p-value was between 0,05 and $0,1(0,05<\mathrm{p}<0,1)$ were taken as marginal.

\section{Results}

Audio-perceptive analysis

According to the criteria adopted in the analysis, children belonging to GIII presented typical productions (target productions), both of / $\mathrm{t} /$ and of $/ \mathrm{k} /$.

Children belonging to GII, presented 15 typical productions of /t/; 20 typical productions of $/ \mathrm{k} /$; 15 substitutions of $/ \mathrm{t} / / \mathrm{k} /$ and 10 substitutions of / $\mathrm{t} / \mathrm{k} / \mathrm{k} /$.

Eventually, children belonging to GI presented 17 target productions of /t/; 20 target productions of $/ \mathrm{k} / ; 13$ substitutions of $/ \mathrm{t} / 2 / \mathrm{k} / ; 08$ substitutions of $/ \mathrm{k} / \mathrm{\prime} / \mathrm{t} / \mathrm{and}$ two distorted productions of $/ \mathrm{k} /$ (characterized as a fronting production of $/ \mathrm{k} /$ ).

\section{Acoustical Analysis}

Acoustical parameters validation: since we haven't found any study dealing with the description of the acoustical parameters needed to distinguish /t/ and / $\mathrm{k}$ / in Brazilian Portuguese, a validation of all acoustical parameters based on the speech productions of a typical adult and on the three kids with typical productions was previously held.

It was verified that the typical adult uses all the acoustical parameters adopted to distinguish /t/ from $/ \mathrm{k} /$, in both vowel contexts (/a/ and /u/). Likewise, the three kids from GIII used the same parameters to distinguish /t/ and / $/$ /, although two kids didn't use all the acoustical parameters to enforce such distinction. The results of acoustical analysis are summarized in Table 01, as follows:

Although the acoustical analysis of children belonging to GIII suggests certain instability in their productions, they are able to use $75 \%$ of all acoustical parameters to distinguish $/ \mathrm{t} /$ and $/ \mathrm{k} /$, what possibly explains why the contrast is considered "typical" by the listeners.

In the next item, we'll go through the data obtained in the acoustical analysis of the production of children who presented substitutions of the contrast investigated.

Acoustical Analysis - production of children with phonological disorder (GII)

The results obtained for each of the productions from children belonging to GII, in both vowel contexts, are summarized in Table 02, as follows:

Based on the results exposed, two distinct phenomena were observed: (i) categorical substitution between the segments (/t/ and / $/$ and vice versa); (ii) presence of covert contrast in the investigated occlusives.

Among the 25 substitutions between /t/ and k/ , described as audibly categorical, 20 of them (80\%) correspond to covert contrasts according to acoustical analysis.

Acoustical analysis - production of children acquiring the process investigated (GI)

Table 03, bellow, sums up the results obtained in the analyses.

Just like in the productions of children from GII (that is, younger children), we also identified both categorical substitution between the segments (/ $\mathrm{t} /$ and $/ \mathrm{k}$ / and vice versa), and covert contrasts in the stops investigated.

We could see that among the 21 substitutions of $/ \mathrm{t} /$ and $/ \mathrm{k} /$, described as audibly categorical, 12 $(57,14 \%)$ are characterized as covert contrasts by acoustical analysis.

In the next item I will discuss the results considered as most relevant.

a The criterion usually accepted in literature so that we can consider that a certain contrast was acquired by the child indicates that the child should get the position of a certain syllable $75 \%$ right $10,11,12$. 
TABLE 1. F values obtained in the linear Hierarchical Model for the production of children belonging to GIII and the typical adult, in context of the vowel /a/. Meaningful p values are in boldface, marginal p values are underlined, and the blank cells don't show any significance.

Burst Spectrum

\begin{tabular}{|c|c|c|c|c|c|c|c|c|}
\hline \multirow{2}{*}{ Subjects } & \multicolumn{5}{|c|}{ Burst Spectrum } & CV & \multicolumn{2}{|c|}{ Durational pattern } \\
\hline & Peak & Centroid & $\begin{array}{l}\text { Standard } \\
\text { deviation }\end{array}$ & Skewness & Kurtosis & Onset F2 & $\begin{array}{c}\% \text { da } \\
\text { closura }\end{array}$ & $\begin{array}{l}\% \text { do } \\
\text { burst }\end{array}$ \\
\hline $\begin{array}{c}\text { Typical } \\
\text { Adult }\end{array}$ & $\begin{array}{c}52,85 \\
* * *\end{array}$ & 8,46 *** & $5,85 * *$ & $10,42 * * *$ & 4,29 * & $101,88 * * *$ & $33,33 * * *$ & 40,00 *** \\
\hline $\begin{array}{l}\text { Typical } \\
\text { child1 }\end{array}$ & $5,29 * *$ & 3,41 * & 4,54 * & & & $13,47 * * *$ & $\underline{2,85}$ & $3,53 *$ \\
\hline $\begin{array}{l}\text { Typical } \\
\text { child2 }\end{array}$ & $\begin{array}{c}13,12 \\
* * *\end{array}$ & $5,59 * *$ & 4,54 ** & $7,30 * *$ & 4,46 ** & $18,89 * * *$ & & \\
\hline $\begin{array}{l}\text { Typical } \\
\text { child3 }\end{array}$ & $6,15 * *$ & 3,30 * & $10,36 * * *$ & 4,90 * & $7,43 * *$ & $24,40 * * *$ & 7,16 ** & 5,84 ** \\
\hline
\end{tabular}


TABLE 02. F values obtained in the linear Hierarchical Model for the production of children belonging to GII in context of the vowels /a/ and /u/ . Meaningful p values are in boldface, marginal p values are underlined, and the blank cells don’t show any significance.

Analysis of the contrast between /t/ and / $k$ / in context of the vowel/a/

\begin{tabular}{|c|c|c|c|c|c|c|c|c|c|}
\hline \multirow{2}{*}{$\begin{array}{l}\text { Subjects } \\
\text { and } \\
\text { repetitions }\end{array}$} & \multicolumn{5}{|c|}{ Burst Spectrum } & \multirow{2}{*}{$\begin{array}{c}\text { CV } \\
\text { Transitions }\end{array}$} & \multicolumn{3}{|c|}{ Durational pattern } \\
\hline & \multirow[t]{2}{*}{ Peak } & \multirow[t]{2}{*}{ Centroid } & \multirow[t]{2}{*}{$\begin{array}{l}\text { Standard } \\
\text { deviation }\end{array}$} & \multirow[t]{2}{*}{ Skewness } & \multirow[t]{2}{*}{ Kurtosis } & & \multirow[t]{2}{*}{$\begin{array}{c}\% \text { da } \\
\text { closura }\end{array}$} & \multicolumn{2}{|c|}{$\%$ do burst } \\
\hline CPD1_R1 & & & & & & & & $\underline{117,58}$ & CC \\
\hline CPD1_R2 & 385,01 * & & & & & & & & CC \\
\hline \multicolumn{10}{|l|}{ CPD1_R3 } \\
\hline CPD1_R4 & & & & & & $238,03^{*}$ & & & $\overline{C C}$ \\
\hline \multicolumn{10}{|l|}{ CPD1_R5 } \\
\hline \multicolumn{10}{|l|}{ CPD2_R1 } \\
\hline CPD2_R2 & & & & & & & 112,19 & & CC \\
\hline CPD2_R3 & & & & & 81,62 & & & & $\overline{C C}$ \\
\hline CPD2_R4 & & & 61,82 & & & & & & $\overline{C C}$ \\
\hline CPD2_R5 & & 6422,50 * & & & & & & & CC \\
\hline \multicolumn{10}{|l|}{ CPD3_R1 } \\
\hline \multicolumn{10}{|l|}{ CPD3_R2 } \\
\hline CPD3_R3 & & & & 1005,08 * & 330,08 ** & & & 161,43 ** & CC \\
\hline CPD3_R4 & & & & & & & 58,48 & & CC \\
\hline CPD3_R5 & & 674,94 * & & & & & 428,93 * & 307,71 * & CC \\
\hline
\end{tabular}

Analysis of the contrast between $/ \mathrm{t} /$ and $/ \mathrm{k} /$ in context of the vowel $/ \mathbf{u} /$

\begin{tabular}{|c|c|c|c|c|c|c|c|c|c|}
\hline \multirow{2}{*}{$\begin{array}{l}\text { Subjects } \\
\text { and } \\
\text { repetitions }\end{array}$} & \multicolumn{5}{|c|}{ Burst Spectrum } & \multirow{2}{*}{$\begin{array}{c}\mathrm{CV} \\
\text { Transitions } \\
\text { Onset F2 }\end{array}$} & \multicolumn{3}{|c|}{ Durational pattern } \\
\hline & Peak & Centroid & $\begin{array}{l}\text { Standard } \\
\text { deviation }\end{array}$ & Skewness & Kurtosis & & $\begin{array}{c}\% \text { da } \\
\text { closura }\end{array}$ & $\%$ do bur & \\
\hline CPD1_R1 & 124,87 & & & & & & & & CC \\
\hline CPD1_R2 & & & & & 74,75 & 113,06 & & & $\mathrm{CC}$ \\
\hline CPD1_R3 & 67,16 & & & & & 198,58 * & & & CC \\
\hline \multicolumn{10}{|l|}{ CPD1_R4 } \\
\hline CPD1_R5 & & 92,02 & & & & 101,62 & & & CC \\
\hline \multicolumn{10}{|l|}{ CPD2_R1 } \\
\hline CPD2_R2 & & & & & & & 112,19 & & $\mathrm{CC}$ \\
\hline CPD2_R3 & & & & & $\underline{81,62}$ & & & & CC \\
\hline CPD2_R4 & & & $\underline{61,82}$ & & & $\underline{74,35}$ & & & $\mathrm{CC}$ \\
\hline CPD2_R5 & & 6422,50 * & & & & $\underline{57,35}$ & & & $\mathrm{CC}$ \\
\hline \multicolumn{10}{|l|}{ CPD3_R1 } \\
\hline \multicolumn{10}{|l|}{ CPD3_R2 } \\
\hline CPD3_R3 & & & & $1005,08^{* *}$ & $330,08^{\star}$ & & & $161,43^{*}$ & $\mathrm{CC}$ \\
\hline CPD3_R4 & & & & & & & $\underline{58,48}$ & & $\mathrm{CC}$ \\
\hline CPD3_R5 & & 674,94 * & & & & & 428,93 * & 307,71 * & $\mathrm{CC}$ \\
\hline
\end{tabular}


TABLE 03. F values obtained in the linear Hierarchical Model for the production s of contrasts between $/ \mathrm{t} / \mathrm{and} / \mathrm{k} /$ in context of the vowels /a/ and /u/ from children belonging to GI . Meaningful $p$ values are in boldface, marginal $p$ values are und erlined, and the blank cells don’t show any significance.

Analysis of the contrast between / $t /$ and $/ k /$ in context of the vowel /a/

\begin{tabular}{|c|c|c|c|c|c|c|c|c|}
\hline \multirow{2}{*}{$\begin{array}{l}\text { Subjects } \\
\text { and } \\
\text { repetitions }\end{array}$} & \multicolumn{5}{|c|}{ Burst Spectrum } & \multirow{2}{*}{$\begin{array}{c}\mathrm{CV} \\
\text { Transitions } \\
\text { Onset F2 }\end{array}$} & \multicolumn{2}{|c|}{ Durational pattern } \\
\hline & Peak & Centroid & $\begin{array}{l}\text { Standard } \\
\text { deviation }\end{array}$ & Skewness & Kurtosis & & $\begin{array}{c}\% \text { da } \\
\text { closura }\end{array}$ & $\%$ do burst \\
\hline \multicolumn{9}{|l|}{ YC1_R1 } \\
\hline YC1_R2 & & & 200,09 * & 1048,28 * & & & & $\mathrm{CO}$ \\
\hline \multicolumn{9}{|l|}{ YC1_R3 } \\
\hline \multicolumn{9}{|l|}{ YC1_R4 } \\
\hline YC1_R5 & & & 206,67 * & 293,57 * & & & & $\mathrm{CC}$ \\
\hline \multicolumn{9}{|l|}{ YC2_R1 } \\
\hline \multicolumn{9}{|l|}{ YC2_R2 } \\
\hline \multicolumn{9}{|l|}{ YC2_R3 } \\
\hline YC2_R4 & & & & & & 611,07 * & & $\mathrm{CC}$ \\
\hline YC2_R5 & 11118,2 ** & & 292,13 * & 2391,53 ** & & $566,84^{*}$ & & $\mathrm{CO}$ \\
\hline \multicolumn{9}{|l|}{ YC3_R1 } \\
\hline \multicolumn{9}{|l|}{ YC3_R2 } \\
\hline YC3_R3 & $\underline{58,38}$ & & & & & & $107,75^{*}$ & CC \\
\hline YC3_R4 & & & & & & $\underline{43,74}$ & & $\mathrm{CC}$ \\
\hline YC3_R5 & & & & & & & & \\
\hline
\end{tabular}

Analysis of the contrast between $/ \mathbf{t} /$ and $/ \mathbf{k} /$ in context of the vowel / $\mathbf{u} /$

\begin{tabular}{|c|c|c|c|c|c|c|c|c|}
\hline \multirow{2}{*}{$\begin{array}{l}\text { Subjects } \\
\text { and } \\
\text { repetitions }\end{array}$} & \multicolumn{5}{|c|}{ Burst Spectrum } & \multirow{2}{*}{$\begin{array}{c}\mathrm{CV} \\
\text { Transitions } \\
\text { Onset F2 }\end{array}$} & \multicolumn{2}{|c|}{ Durational pattern } \\
\hline & Peak & Centroid & $\begin{array}{l}\text { Standard } \\
\text { deviation }\end{array}$ & Skewness & Kurtosis & & $\begin{array}{c}\% \mathrm{da} \\
\text { closura }\end{array}$ & $\%$ do burst \\
\hline \multicolumn{9}{|l|}{ YC1_R1 } \\
\hline YC1_R2 & & & 200,09 * & 1048,28 * & & & & CC \\
\hline \multicolumn{9}{|l|}{ YC1_R3 } \\
\hline \multicolumn{9}{|l|}{ YC1_R4 } \\
\hline YC1_R5 & & & 206,67 * & 293,57 * & & & & CC \\
\hline \multicolumn{9}{|l|}{ YC2_R1 } \\
\hline \multicolumn{9}{|l|}{ YC2_R2 } \\
\hline \multicolumn{9}{|l|}{ YC2_R3 } \\
\hline YC2_R4 & & & & & & 611,071 * & & CC \\
\hline YC2_R5 & 11118,2 ** & & 292,13 * & 2391,53 ** & & $566,84^{*}$ & & $\overline{C C}$ \\
\hline \multicolumn{9}{|l|}{ YC3_R1 } \\
\hline \multicolumn{9}{|l|}{ YC3_R2 } \\
\hline YC3_R3 & 58,38 & & & & & & $107,75^{*}$ & CC \\
\hline YC3_R4 & & & & & & 43,74 & & $\overline{C C}$ \\
\hline YC3_R5 & & & & & & & & \\
\hline
\end{tabular}




\section{Discussion}

The first result which deserves to be highlighted is related to the acoustical analysis of the typical productions of the contrast between / $\mathrm{t} /$ and $/ \mathrm{k} /$ made by the adult speaker and children from GII, who present typical productions of such contrast.

Despite the fact that the audio-perceptive analysis is able to perceive the phonological contrast between $/ \mathrm{t} /$ and $/ \mathrm{k} /$ made by the adult speaker and children form GIII, the acoustical analysis was able to detect some difference between the adult and the children not only in the number of parameters used to mark this contrast, but also in the distinction magnitude. The productions of children from GIII seem to be more unstable if compared to the typical productions of the adult speaker.

This point leads to a study 13 which warns us about the fact that motor control over the tongue movements during speech production lasts until the age of 07 years old, at least.

Secondly, our results reveal that in both GI and GII that are covert contrasts in the substitution errors of the stops investigated (80 and 57,14\% respectively).

In agreement with our outcomes, the presence of covert contrast in substitution errors committed both by children in language acquisition and by children with phonological disorder has been described by different authors of different studies using an instrumental methodology (acoustical and/or articulatory) to analyze speech production 1-6, 14-16.

Nevertheless, none of the studies mentioned above focuses on which acoustic cues or on which distinctive magnitude they are used to mark a certain phonic contrast.

I saw that both GI and GII use a distinctive magnitude which is not enough for the listener to audibly identify this contrast.

I found only one study 17 which describes describing both acoustic cues and their magnitude to mark a certain phonic distinction. Although the contrast investigated by these authors refer to the contrast between /s/ e /?/ , have as subjects adults and children in process of acquisition of the contrast investigated and also speakers of English and Japanese, their outcomes greatly support the ones outlined by us.
Highlighted, specially, two implications these findings to clinical practice of the speech pathologist. The first implication is related to investigation method (assessment tool) of speech production. Once it was detected the presence of covert contrasts (both in speech production of younger children and in the speech production of children with phonological disorder), it is necessary to incorporate the instrumental assessment (acoustic or articulatory) in the clinical practice not only to enable the detection of covert contrast, but also it is necessary to consider this type of production as a category of analysis in speech production of children.

Analogously, the second implication concerning to therapy of children with phonological disorder. The detection and the identification of which acoustic cues and, also, in what magnitude, children mastering to establish a specific phonic contrast, should direct the process the therapeutic process aiming its focus from the standpoint of auditory perception.

Next, I'll have some final remarks about our study.

\section{Conclusion}

The results of this study support the hypothesis raised in the introduction of this paper that many of the phonic substitutions audibly perceived as categorical are in fact, convert contrasts.

Among the 25 audibly detected as categorical in the speech productions of GII, 20 (80\%) stand for convert contrasts. Likewise, among the 21 substitutions audibly detected as categorical in the speech productions of GI, $12(57,14 \%)$ stand for covert contrasts. These results suggest that transcription alone is not adequate to describe phonological system of the children and needs to be supplemented by other measures, such as acoustic analysis.

In addition, children from GII and GI used a distinctive magnitude not enough to be audibly perceived by the listener as covert contrast.

Therefore, it seems to us that further investigation of other contrasts produced by children with typical and deviant language development is very relevant, aiming to describe which acoustic cues children use to start distinguishing a certain phonological contrast, and contributing to a better therapeutic prescription for those children with phonological disorders. 


\section{References}

1. Macken MA, Barton D. The acquisition of the voicing contrast in English: a study of voice onset time in word-initial stop consonants. Journal of Child Language.1980;7:41-74.

2. Maxwell EM. The use of acoustic phonetics in phonological analysis. Journal of the National Student Speech Language Hearing Association. 198;9:20-37.

3. Scobbie JM, Gibbon F, Hardcastle WJ, Fletcher P. Covert contrast as a stage in the acquisition of phonetics and phonology. In: Broe M, Pierrehumbert J editors. Papers in Laboratory Phonology V: Language Acquisition and the Lexicon. 2000;5(1):194-207.

4. Edwards J, Gibbon F, Fourakis M. On discrete changes in the acquisition of the alveolar/velar stop consonant contrast. Language and Speech.1997;20:203-10.

5. Berti LC. Um estudo comparativo de medidas acústicas em crianças com e sem problemas na produção de /s/ e /?/. Estudos Linguísticos XXXIV. 2005;34(1):1337-42.

6. Rodrigues LL. O caráter exploratório das flutuações da fala infantil. Estudos Linguísticos XXXV. 2006;35(1):1189-95.

7. Hewlett N. Acoustic properties of $/ \mathrm{k} /$ and $/ \mathrm{t} /$ in normal and phonological disordered speech. Clinical Linguistics and Phonetics. 1988;2:29-45.

8. Boersma P, Weenink D. Praat: doing phonetics by computer (Versão 5.0.30) [Programa de computador]. Compilado de http://www.praat.org/ em novembro de 2008.

9. Raudenbush SW, Bryk AS, Cheong YF, Congdon R. HLM 6: Hierarquical linear and nonlinear modeling. Lincolnwood, IL: Scientific Software International. 2004.
10. Templin M. Certain language skills in children. Minneapolis: Univ. of Minnesota Press;1957.

11. Prather E, Hedrick D, Kern D. Articulation development in children aged two to four years. Journal of Speech and Hearing Disorders. 1975;403:179-91.

12. Smit AB, Hand L, Freilinger JJ, Bernthal JE, Bird A. The Iowa articulation norms project and its Nebraska replication. Journal of Speech and Hearing Disorders. 1990; 55:779-98.

13. Nittrouer S. Children learn separate aspects of speech production at different rates: evidence from the spectral moments. Journal of the Acoustical Society of America. 1995;97:520-30.

14. Hewlett N, Waters D. Gradient change in the acquisition of phonology. Clinical Linguistics and Phonetics. 2004;18(6-8):523-33.

15. Scobbie JM, Wood SE, Wrench AA. Advances in EPG for treatment and research: an illustrative case study. Clinical Linguistics and Phonetics. 2000;18:373-89.

16. Gibbon F. Undifferentiated lingual gestures in children with articulation/phonological disorders. Journal of Speech, Language and Hearing Reasearch. 1999;42:382-97.

17. Li F, Edwards J, Beckman M. Contrast and covert contrast: the phonetic development of voiceless sibilant fricatives in English and Japanese toddlers. Journal of Phonetics. 2009;37(2):189-211. 